\title{
Aqueous Extract of Anticancer Drug CRUEL Herbomineral Formulation Capsules Exerts Anti-proliferative Effects in Renal Cell Carcinoma Cell Lines
}

\author{
Shiv Prakash Verma ${ }^{1}$, Saumya Sisoudiya ${ }^{2}$, Parimal Das $^{1 *}$
}

\begin{abstract}
Purpose: Anti-cancer activity evaluation of aqueous extract of CRUEL (herbomineral formulation) capsules on renal cell carcinoma cell lines, and exploration of mechanisms of cell death. Materials and Methods: To detect the cytotoxic dose concentration in renal cell carcinoma (RCC) cells, MTT assays were performed and morphological changes after treatment were observed by inverted microscopy. Drug effects against RCC cell lines were assessed with reference to cell cycle distribution (flow cytometry), anti-metastatic potential (wound healing assay) and autophagy(RT-PCR). Results: CRUEL showed anti-proliferative effects against RCC tumor cell lines with an IC50 value of $\approx 4 \mathrm{mg} / \mathrm{mL}$ in vitro., while inducing cell cycle arrest at S-phase of cell cycle and inhibiting wound healing. LC3 was found to be up-regulated after drug treatment in RT-PCR resulting in an autophagy mode of cell death. Conclusions: This study provides the experimental validation for antitumor activity of CRUEL.
\end{abstract}

Keywords: Cruel, uok 146 - achn - renal cell carcinoma - cell cycle - autophagy

Asian Pac J Cancer Prev, 16 (18), 8419-8423

\section{Introduction}

Cancer is one of the most deadly diseases for the society and one of the most challenging diseases for the scientists all over the world to tackle with. Drugs and therapies available until now are still not effective enough for most of the cancer types and have side effects. People are, therefore looking towards traditional Ayurveda system of medicine to find out relatively safe and cost effective solution for cancer treatment. Herbometallic and herbomineral therapeutics are being considered as promising alternative medicines for treatment of diseases like cancer. Rasa shastra is the branch of Ayurveda which deals with medicinal properties of herbometallic and herbomineral preparations and the drugs which are used are known as Rasa Aushadhi. These therapeutics are claimed for faster in action and more efficient as compared to only herbal drugs. Herbomineral drugs are prepared by anaerobic cooking which converts the toxic mega particles of metal into safe and efficacious nanoparticles and even smaller picoparticles explaining the usefulness of these drugs as effective medicines for cancer (Sheikh et al., 2012).

Cruel Capsule is an ayurvedic proprietary medicine marketed by Virgo UAP Pharma Ltd. and UNJHA ayurvedic pharmacy India. It is a combination of antineoplastic, tissue promoting and anti- inflammatory herbo-minerals. It is claimed to be useful in different type of benign, malignant and degenerative conditions. Its constituents include extracts of various plants and several bhasmas with claimed anti- cancerous potential along with beneficial anti-oxidant activity. Ingredients are Sarveswar Parpati, Suvarna Bhasma, Rasakarpoor, Swet Mirch, Abhrak Bhasma, Ext Punarnava, Ext. Yastimadhu, Ext. Vasa, Hira Bhasma, Rasasindur, Tamra Bhasma, Lavang, Panna Bhasma, Ext. Saragava, Ext. Rohitak, Ext. Guduchi and Excipients. All the constituents of cruel capsule have reported benefits to enhance the immune response against cancerous cells, some are described here. Piper nigrum extract has antimutagenic, antitumor, immunomodulatory, antimetastatic and many more activity shown in different experimental models (Hamss et al., 2003; Sunila et al., 2004; Ahmad et al., 2012). Boerhaavia diffusa exhibits antiproliferative and antiestrogenic properties in MCF-7 cells, protective Effects against gamma radiation induced DNA damage in mice and possess hepatoprotective activity in acetaminophen-induced liver damage in rats (Manu et al., 2007; Sreeja et al., 2009; Olaleye et al., 2010). Ethanolic extract of Boerhaavia diffusa showed inhibition of S-phase of cell cycle and cell growth in Hela cell line (Sultana et al., 2014). Glycyrrhiza glabra inhibits angiogenesis, tumor growth, migration, alleviates tumorigenic effect of endocrine-disrupting chemicals and act as a chemopreventive agent (Fu et al., 2004; Nagaraj et al., 2012; Chu et al., 2014). Adhatoda vasica has antimutagenic activity which can be attributed to its

\footnotetext{
${ }^{1}$ Centre for Genetic Disorders, Faculty of Science, Banaras Hindu University, Varanasi, ${ }^{2}$ VIT University, Vellore, India *For correspondence: hellow_parimal@yahoo.com
} 
restoring potential on antioxidant status in $\mathrm{CdCl} 2$ induced renal oxidative stress and genotoxicity in mice (Jahangir et al., 2006). It has protective effect against D-galactosamine induced liver damage in rats as well as radiation-induced hematological alterations in mice (Kumar et al., 2005; Jayakumar et al., 2009). Syzygium aromaticum known as clove has chemopreventive potential due to its apoptogenic and anti-proliferative properties (Lee et al., 2001; Banerjee et al., 2006; Jaganathan et al., 2012). Moringa oleifera extracts had strong antiproliferative, apoptosis inducing and antioxidant potential and hence it has cancer chemoprevention property (Sreelatha et al., 2009; Verma et al., 2009; Sreelatha et al., 2011; Sharma et al., 2012). Tecomella undulate also has antioxidant potential (Kumar et al., 2012), bark extract induce apoptosis in K562 cells (Ravi et al., 2011). Tinospora cordifolia has anti-proliferative, differentiation-inducing and anti-migratory/anti-metastatic potential in glioma cells (Mishra et al., 2013). It has antineoplastic activity in HeLa cells and Ehrlich Ascites Carcinoma Bearing Mice (Jagetia et al., 1998; Jagetia et al., 2006). Scientific evidence for the therapeutic potential of Cruel in cancer is limited because formulation complexity does not facilitate investigations. In this study aqueous extract of Cruel was applied on renal cell carcinoma (RCC) cell lines UOK146 and ACHN to understand the anticancerous action of Cruel capsule in vitro.

\section{Materials and Methods}

\section{Cell culture and drug}

UOK146 renal cell carcinoma cell line has $(\mathrm{X} ; 1)$ (p11.2; 21 ) chromosomal translocation leading to the fusion of PRCC gene at 1q21.2 to the TFE3 gene at $\mathrm{Xp} 11.2$ leading to the formation of a oncogenic fusion protein PRCC-TFE3 (Sidhar et al., 1996). ACHN is a cancer cell line derived from a metastatic human renal adenocarcinoma and it bears a deletion of Sav (Tapon et al., 2002) which suggests the compromised Hippo pathway (Zhao et al., 2007). Cells were maintained in DMEM supplemented with $10 \%$ fetal bovine serum and antibiotics (100 U/ml penicillin, $100 \mu \mathrm{g} / \mathrm{ml}$ streptomycin) and grown in $5 \%(\mathrm{v} / \mathrm{v}) \mathrm{CO}_{2}$ in a humidified incubator. Cruel capsule from VIRGO UAP Pharma Pvt. Ltd. was dissolved in DMEM at $50 \mathrm{mg} / \mathrm{ml}$ concentration, incubated at room temperature overnight, centrifuged and supernatant was taken for the treatment.

\section{Microscopy:}

Changes in morphological characteristics in renal cell carcinoma cells following Cruel treatment were assessed by Phase contrast microscopy (Motic, China). Cells were first cultured in 12 well plate for the microscopic observation. Following Cruel treatment at $4 \mathrm{mg} / \mathrm{ml}$ concentration ( $\approx \mathrm{IC}_{50}$ concentration) for 24 hours images were captured by Canon Power Shot A640 camera at 10X objective of microscope.

\section{MTT assay}

MTT assay was performed according to Waheed et al., 2013 with slight modification. Briefly, from exponentially growing $80 \%$ confluent T25 flask cells were seeded in 96-well plate in complete DMEM medium. After $24 \mathrm{~h}$ cells were incubated with varying concentrations $(2,4,6,8$ and $10 \mathrm{mg} / \mathrm{ml})$ of extract in triplicates for $24 \mathrm{~h}$. After that growth media changed with $0.5 \mathrm{mg} / \mathrm{ml}$ 3- (4,5-dimethylthiazol-2-yl)-2,5-diphenyl tetrazolium bromide (MTT) containing media and incubated for $4 \mathrm{~h}$ at $37^{\circ} \mathrm{C}$. After that, media was removed and blue coloured formazan was extracted in $600 \mu \mathrm{l}$ of DMSO at room temperature. The purple color end products were quantified by measuring absorbance (OD $570 \mathrm{~nm}$ ) with a spectrophotometer (Amersham). Antiproliferative activity was calculated using the following formula:

Percentage inhibition $=\underline{\text { OD control }- \text { OD treated }} \times 100$ OD control

\section{Results}

\section{Antiproliferative effect}

Cruel's antiproliferative effect on renal cell carcinoma cells was evaluated by MTT cell viability assay. Cells displayed a dose dependent decrease in cell viability following drug treatment for 24 hours. Addition of Cruel at different concentrations i.e. 2, 4, 6, 8 and $10 \mathrm{mg} / \mathrm{ml}$ to RCC cells for $24 \mathrm{~h}$ inhibited the growth as mentioned and plotted a graph to visualize the percentage inhibition

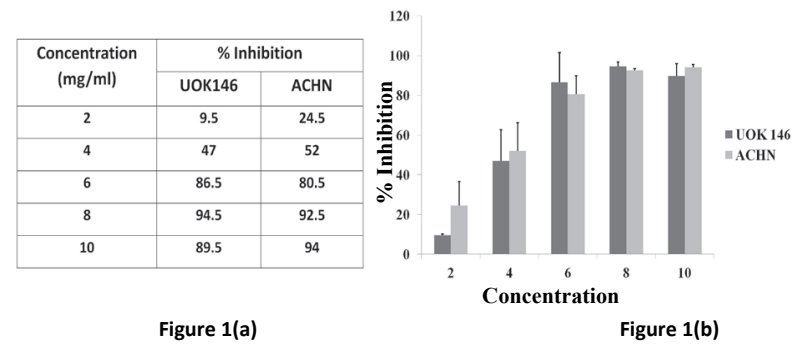

Figure 1. Dose Response Graph: (a) Table showing the dose dependent \% cell death of RCC Cells and its (b) Graphical presentation
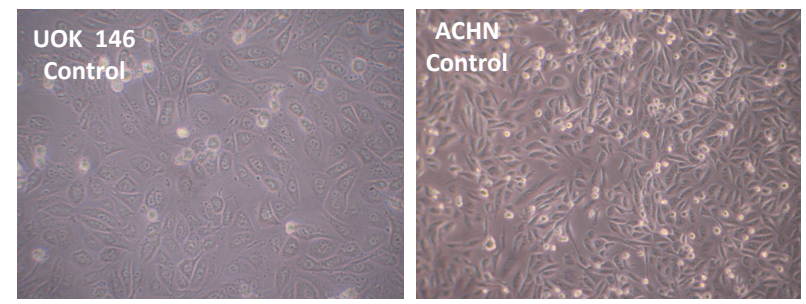

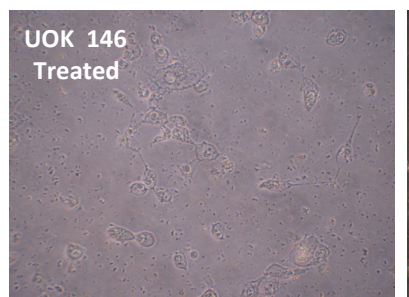

Figure 2 (a)

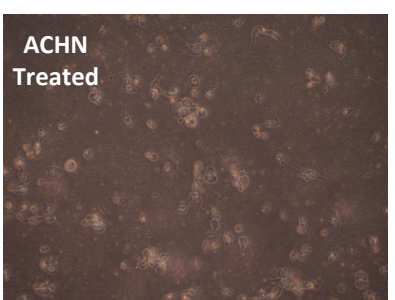

Figure 2 (b)
Figure 2. Phase Contrast Microscopy: Images of RCC Cells at same magnification (a) UOK 146 cells: Upper panel is control and lower is $4 \mathrm{mg} / \mathrm{ml}$ cruel treated (b) ACHN: Upper panel is control and lower is $4 \mathrm{mg} / \mathrm{ml}$ cruel treated 
Aqueous Extract of Anticancer Drug CRUEL Capsules Exerts Anti-Proliferative Effects in Renal Cell Carcinoma Cells

with concentration (Figure 1). $\mathrm{IC}_{50}$ was determined by dose response curve plotted between the \% inhibition of cell viability and doses concentration, and estimated $\mathrm{IC}_{50}$ is nearly 4.8 and $4.0 \mathrm{mg} / \mathrm{ml}$ for UOK 146 and $\mathrm{ACHN}$ respectively.

\section{Morphology}

Cruel's effect on RCC cells was evaluated by phase contrast microscopy. After $4 \mathrm{mg} / \mathrm{ml}$ of drug treatment cells were incubated for $24 \mathrm{~h}$. Cells became rounded, detached from the flask surface and started floating into the growth media as suspension which is a characteristic feature of cell death (Figure 2).
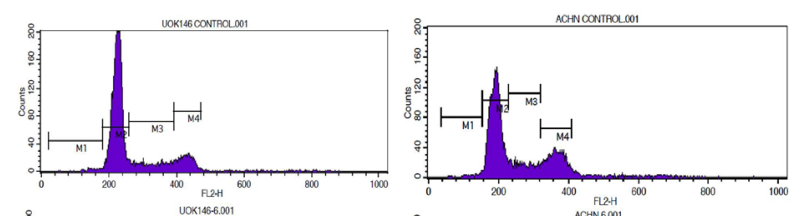

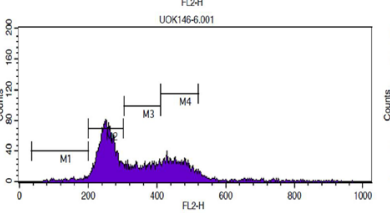

Figure 3(a)

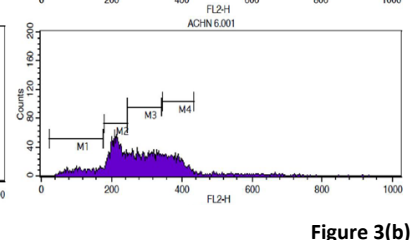

Figure 3. Flow Cytometry Analysis: M1, M2 and M3 and M4 in the histogram denotes the cells in sub-G1, G1, S and G2+M phase respectively (a) UOK 146 cells: Upper panel control and lower is $6 \mathrm{mg} / \mathrm{ml}$ cruel treated (b) ACHN: Upper panel Control and lower Panel Treated
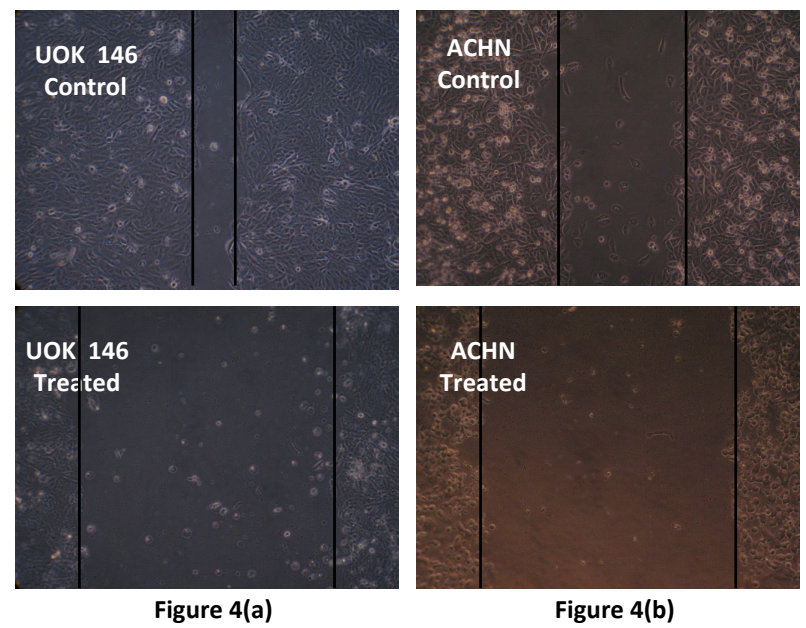

Figure 4. Cell migration assay: (a) UOK 146 cells: Upper panel is control and lower is $4 \mathrm{mg} / \mathrm{ml}$ cruel treated (b) ACHN: Upper panel is control and lower is $4 \mathrm{mg} / \mathrm{ml}$ cruel treated
Cell cycle analysis

Cruel's effect on cell cycle stages were assessed by flow cytometry after staining with PI, a DNA binding dye. RCC cells were treated with $6 \mathrm{mg} / \mathrm{ml} \mathrm{Cruel} \mathrm{and}$ compared with control cells. Change in cell cycle stages were observed, Cells in S and G2/M population increases after treatment denoting the cell cycle arrest at these stages. Cells in different cell cycle stages and histogram were mentioned in the Table 2 and Figure 3 respectively.

\section{Cell migration}

Inhibition in Cell migration was studied by wound healing assay in RCC cells after $4 \mathrm{mg} / \mathrm{ml}$ cruel treatment. The extent of scratch wound closure was monitored under phase-contrast microscope and photographed. After drug treatment cell migration into the open space (scratch in the confluent cell layer) is inhibited as compared to control. This denotes that Cruel has property to inhibit the cell migration (Figure 4).

\section{Gene expression analysis}

Mode of cell death in RCC cells induced by Cruel treatment was examined at molecular level by gene expression analysis. BAX, a proapoptotic marker and LC3 an autophagy marker gene were used for quantitative RT-

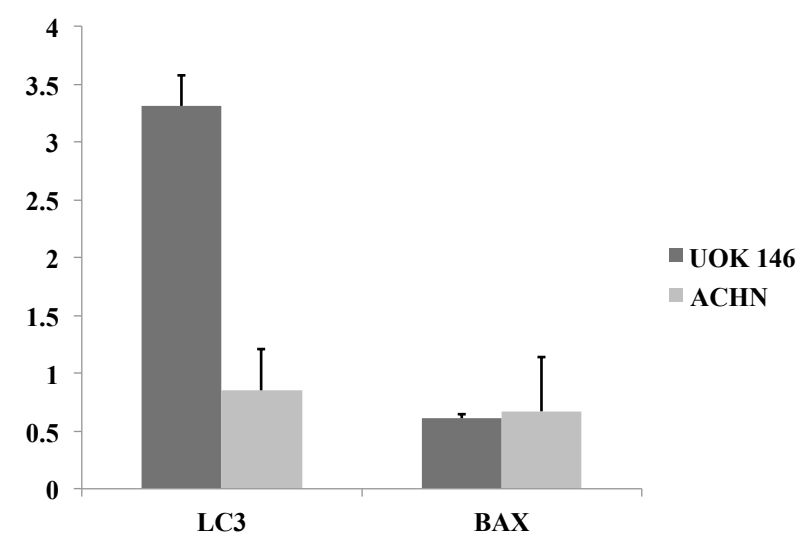

Figure 5. Real Time PCR Analysis: Expression of LC3 and BAX at transcript level after Cruel treatment

Table 2. Percentage of Cell Cycle Stages

\begin{tabular}{lrrrrr}
\hline Cell cycle stage & \multicolumn{2}{c}{ UOK146 } & & \multicolumn{2}{c}{ ACHN } \\
\cline { 2 - 3 } \cline { 5 - 6 } & Control & $6 \mathrm{mg} / \mathrm{ml}$ & & Control & $6 \mathrm{mg} / \mathrm{ml}$ \\
\hline Sub G1 phase(M1) & $1.31 \%$ & $1.94 \%$ & & $1.25 \%$ & $10.18 \%$ \\
G1 phase(M2) & $73.15 \%$ & $46.29 \%$ & $58.73 \%$ & $29.11 \%$ \\
S phase(M3) & $13.13 \%$ & $22.15 \%$ & & $14.36 \%$ & $34.01 \%$ \\
G2/ M phase(M4) & $11.73 \%$ & $25.33 \%$ & $22.43 \%$ & $21.86 \%$ \\
\hline
\end{tabular}

Table 1. Primers Sequence Used in the Study

\begin{tabular}{lll}
\hline Primer & \multicolumn{1}{c}{ Sequence (5'-3') } & Reference \\
\hline GAPDH-Forward & AGGGCTGCTTTTAACTCTGGT & Ito et al., 2007 \\
GAPDH- Reverse & CCCCACTTGATTTTGGAGGGA & \\
LC3-Forward & GAGAAGCAGCTTCCTGTTCTGG & Jiang ZF et al., 2012 \\
LC3-Reverse & GTGTCCGTTCACCAACAGGAAG & \\
BAX-Forward & CCCTTTTGCTTCAGGGTTTC & Liu et al., 2008 \\
BAX-Reverse & TGTTACTGTCCAGTTCGTCC & \\
\hline
\end{tabular}


PCR to see the mode of cell death. Quantitative RT-PCR for LC3 showed that cruel treatment increased the level of transcripts up to 3 times as compared to control in UOK 146 and BAX expression is decreased (Figure 5) which indicates autophagy mode of cell death. In ACHN both LC3 and BAX is slightly decreased and hence in this cell line mechanism of cell death was not confirmed. These results primarily indicate that Cruel may induce cell death by autophagy mode.

\section{Discussion}

Ayurveda the science of life is a traditional medicine system used by Indian population. Medicinal plants were the primary source for the therapeutics preparation in Ayurveda during the days of Charaka and Sushruta. A lot of plant products have been studied well and described for their medicinal properties. In $8^{\text {th }}$ century AD Indian alchemist Nagrjuna prescribed the use of metals (e.g., mercury, lead, cadmium, iron, and zinc) and minerals (e.g., mica) as medicinal agents. It has been proved that if potentially toxic macro- or micro particles of heavy metals are converted into nano- or pico particles it could be nontoxic (Sheikh et al., 2012). Researchers are looking for some novel phytotherapy for cancer prevention using these minerals in very low, nontoxic and therapeutically significant amount. Minerals are now widely used in Ayurveda alongwith herbal drugs for its medicinal properties leading to the successful invention of many herbomineral drugs. Herbo mineral drugs are now used for many types of cancer for example it has been used as adjuvant therapy for the improvement of quality of life (QoL) in hepatocellular carcinoma (Jayawardhane et al., 2012). Acute promyelocytic leukemia was treated with a proprietary ayurvedic medicine Navajeevan, Kamadudha Rasa and Keharuba Pisti and patient achieved complete disease remission without any side effects (Prakash et al., 2010). Testosterone propionate-induced BPH in male wistar rats was significantly corrected by herbomineral preparation Ural-BPH (Soni et al., 2014). Herbomineral capsule ALG-06 was used for the hypopigmentation especially in vitiligo (Huma et al., 2014). Khamira Marwarid khas is a herbo-mineral preparation with immunostimulatory effect in murine model (Khan et al., 2014). Las01 a novel herbomineral preparation has been found to be effective as a potent anticancer drug in MCF-7 and Hela cancer cell lines (Sheikh et al., 2012).

Cruel a proprietary ayurvedic medicine for cancer treatment is marketed by UNJHA ayurvedic pharmacy and VIRGO UAP pharma in INDIA. This drug is prescribed for the cancer treatment and hence a detailed experimental study for finding its mechanism of action was attempted in this study. We treated RCC cell lines with aqueous solution of Cruel and observed that cells detaching from the surface indicating its cytotoxic effect on cancer cells. Cell cycle analysis following Cruel treatment revealed that cell was arrested at S and G2/M phase of cell cycle implying that Cruel acts at the level of cell cycle regulation. Migratory capacity of cancer cells is the main cause behind cancer metastasis and dissemination to the other body parts which is the most detrimental property of a cancer. Cruel was tested for its inhibitory action for cancer cell migration and observed that cancer cell migration was significantly inhibited and hence it may be postulated that invasion will also be inhibited qualifying Cruel as a potent anticancer drug with very little to no side effects. Experimental evidences gathered from the present study detailing the mechanism of cell death proves the efficacy of this drug for killing cancer cells. There are mainly three modes of cell death; apoptosis, autophagy and an advanced cell death stage known as necrosis. In apoptosis and autophagy BAX and LC3 are upregulated respectively. In RCC cells Cruel was tested for both autophagy and apoptosis mode of cell death, through gene expression analysis of LC3 and $\mathrm{BAX}$ as markers. Down regulation of BAX expression in both the cell lines and upregulation of LC3expression in UOK146 indicated that autophagy mode of cell death may be the possible mechanism of cell death in RCC cells. Further study, however will be required to see the detailed mechanism of action which will also provide the great opportunity for improvising the drug.

\section{Acknowledgements}

We acknowledge W M Linehan, National Cancer Institute, USA and National Centre for Cell Science, Pune, INDIA (NCCS) for providing the UOK 146 and ACHN cell line respectively. DBT- BHU Interdisciplinary School of Life Sciences (ISLS) Banaras Hindu University, Varanasi, INDIA for Flow Cytometry and Real Time PCR facilities. Indian Council of Medical Research (ICMR), Government of India, New Delhi for fellowship support to Shiv Prakash Verma.

\section{References}

Ahmad N, Fazal H, Abbasi BH, et al (2012). Biological role of Piper nigrum L. (Black pepper): A review. Asian Pac J Trop Biomed, 2, 1945-53.

Banerjee S, Panda CK, Das S (2006). Clove (Syzygium aromaticum $\mathrm{L}$.), a potential chemopreventive agent for lung cancer. Carcinogenesis, 27, 1645-54.

Baranska P, Jerczynska H, Pawlowska Z, Koziolkiewicz W, cierniewski CS (2005). Expression of integrins and adhesive properties of human endothelial cell line EA.hy 926. Cancer Genomics Proteomics, 2, 265-70.

Chu XT, de la Cruz J, Hwang SG, Hong H (2014). Tumorigenic effects of endocrine-disrupting chemicals are alleviated by licorice (Glycyrrhiza glabra) root extract through suppression of AhR expression in mammalian cells. Asian Pac J Cancer Prev, 15, 4809-13.

Fu Y, Hsieh TC, Guo J, et al (2004). Licochalcone A, a novel flavonoid isolated from licorice root (Glycyrrhiza glabra), causes G2 and late-G1 arrests in androgen-independent PC3 prostate cancer cells. Biochem Biophys Res Commun, 322, 263-70.

Hamss RE, Idaomar M, Alonso-Moraga A, Munoz Serrano A (2003). Antimutagenic properties of bell and black peppers. Food Chem Toxicol, 41, 41-7.

Huma A, Rizwani GH, Usman M, et al (2014). Drug development of herbomineral capsule (ALG-06) used for hypopigmentation specially in vitiligo. Pak J Pharm Sci, 27, 1451-7.

Ito TK, Ishii G, Chiba H, Ochiai (2007). The VEGF angiogenic 
Aqueous Extract of Anticancer Drug CRUEL Capsules Exerts Anti-Proliferative Effects in Renal Cell Carcinoma Cells switch of fibroblasts is regulated by MMP-7 from cancer cells. Oncogene, 8, 7194-203.

Jaganathan SK, Supriyanto E (2012). Antiproliferative and molecular mechanism of eugenol-induced apoptosis in cancer cells. Molecules, 17, 6290-304.

Jagetia GC, Nayak V, Vidyasagar MS (1998). Evaluation of the antineoplastic activity of guduchi (Tinospora cordifolia) in cultured HeLa cells. Cancer Lett, 127, 71-82.

Jagetia GC, Rao SK (2006). Evaluation of the antineoplastic activity of guduchi (Tinospora cordifolia) in Ehrlich Ascites carcinoma bearing mice. Biol Pharm Bull, 29, 460-6.

Jahangir T, Khan TH, Prasad L, Sultana S (2006). Reversal of cadmium chloride-induced oxidative stress and genotoxicity by Adhatoda vasica extract in Swiss albino mice. Biol Trace Elem Res, 111, 217-28.

Jayakumar T, Ilayaraja M, Sridhar MP, et al (2009). Protective effect of Adhatoda vasica on D-galactosamine induced liver damage in rats with reference to lipid peroxidation and antioxidant status. J Natural Remedies, 9, 91-8.

Jayawardhane NDN, De Silva RHSK, Tripathi JS, Narasimha Murthy KHHVSS, Tiwari SK (2012). An effective herbomineral treatment as an adjuvant therapy for the improvement of quality of life of hepatocellular carcinoma patient: a case report. Int Res J Pharmacy, 3, 266-70.

Jiang ZF, Shao LJ, Wang WM, Yan XB, Liu RY (2012). Decreased expression of Beclin-1 and LC3 in human lung cancer. Mol Biol Rep, 39, 259-67.

Khan F, Elahi A, Ali S (2014). Khamira marwarid khas, a herbomineral prescription, as mucosal immunopotentiator in murine model. African J Pharmacy Pharmacol, 8, 598-608.

Kumar A, Ram J, Samarth RM, Kumar M (2005). Modulatory influence of Adhatoda vasica Nees leaf extract against gamma irradiation in Swiss albino mice. Phytomedicine, 12, 285-93.

Kumar S, Sharma S, Vasudeva N, Ranga V (2012). In vivo antihyperglycemic and antioxidant potentials of ethanolic extract from Tecomella undulata. Diabetol Metab Syndr, 4, 33.

Lee KG, Shibamoto T (2001). Antioxidant property of aroma extract isolated from clove buds [Syzygium aromaticum (L.) Merr. et Perry]. Food Chemistry, 74, 443-8.

Liu FT, Agrawal SG, Gribben JG (2008). Bortezomib blocks Bax degradation in malignant $\mathrm{B}$ cells during treatment with TRAIL. Blood, 111, 2797-805.

Manu KA, Leyon PV, Kuttan G (2007). Studies on the protective effects of Boerhaavia diffusa L. against gamma radiation induced damage in mice. Integr Cancer Ther, 6, 381-8.

Mishra R, Kaur G (2013). Aqueous ethanolic extract of Tinospora cordifolia as a potential candidate for differentiation based therapy of glioblastomas. PLoS One, 8, 78764.

Nagaraj SRM, Lingaraj SM, Yashaswi B, Kumar A, Salimath BP (2012). MTA1 induced angiogenesis, migration and tumor growth is inhibited by Glycyrrhiza glabra. IOSR $J$ Pharmacy, 2, 34-43.

Olaleye MT, Akinmoladun AC, Ogunboye AA, Akindahunsi AA (2010). Antioxidant activity and hepatoprotective property of leaf extracts of Boerhaavia diffusa Linn against acetaminophen-induced liver damage in rats. Food Chem Toxicol, 48, 2200-5.

Prakash B, Parikh PM, Pal SK (2010). Herbo-mineral ayurvedic treatment in a high risk acute promyelocytic leukemia patient with second relapse: 12 years follow up. J Ayurveda Integr Med, 1, 215-8.

Ravi A, Mallika A, Sama V, et al (2011). Antiproliferative activity and standardization of Tecomella undulata bark extract on K562 cells. J Ethnopharmacol, 137, 1353-9.

Sharma V, Paliwal R, Janmeda P, Sharma S (2012). Chemopreventive efficacy of Moringa oleifera pods 